\title{
Caffeinated and decaffeinated mate tea: Effect of toasting on bioactive compounds and consumer acceptance
}

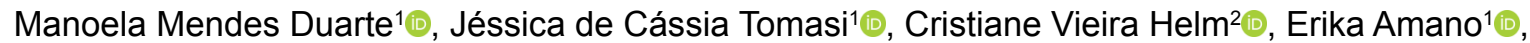

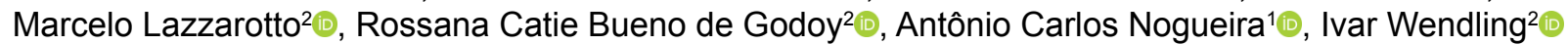

\footnotetext{
1 Universidade Federal do Paraná, Curitiba, PR, Brasil. E-mail: manu.florestal@gmail.com; jehtomasi@gmail.com; erika.amano@gmail.com; acnogueira.ufpr@gmail.com
} \\ 22Embrapa Florestas, Colombo, PR, Brasil. E-mail: cristiane.helm@embrapa.br; marcelo.lazzarotto@embrapa.br; catie.godoy@embrapa.br; ivar.wendling@embrapa.br
}

ABSTRACT: We analyzed the influence of toasting yerba mate on bioactive compounds contents in different genotypes and the consumer acceptance of caffeinated and decaffeinated mate teas. The influence of toasting was studied using 11 genotypes and a control sample, determining the antioxidant capacity, total phenolic compounds, methylxanthines and caffeoylquinic acids before and after toasting. In the acceptance tests, five decaffeinated and six caffeinated teas and two control samples (commercial products) were evaluated separately by 110 consumers. The toasting process reduced the levels of teas bioactive compounds, as well as differences between genotypes were found. After toasting, EC49 and EC37 showed the highest caffeine levels, while EC29 and EC51 presented the lowest levels. In relation to mate tea acceptance, the decaffeinated genotypes EC29 and EC51 performed well, and EC43 and EC33 stood out among the caffeinated ones. In both cases, the genotypes were equal or superior to commercial products. In general, decaffeinated teas were more accepted than caffeinated ones.

Key words: antioxidant capacity; caffeoylquinic acids; llex paraguariensis; methylxanthines; phenolic compounds

\section{Chá mate cafeinado e descafeinado: Efeito da tosta nos compostos bioativos} e aceitação por consumidores

RESUMO: 0 estudo objetivou analisar a influência da tosta da erva-mate nos teores de compostos bioativos de diferentes genótipos e a aceitação por consumidores de chá mate cafeinados e descafeinado. A influência da tosta foi estudada a partir de 11 genótipos e uma amostra controle, determinando-se a capacidade antioxidante, compostos fenólicos totais, metilxantinas e ácidos cafeoilquínicos, antes e após a tosta. Nos testes de aceitação foram avaliados cinco chás descafeinados e seis cafeinados, separadamente, e duas amostras controle (produtos comerciais), provadas por 110 consumidores. 0 processo de tosta influenciou negativamente nos teores de compostos bioativos dos chás, bem como houve diferença entre os genótipos. Para cafeína, EC49 e EC37 apresentaram os maiores teores, enquanto EC29 e EC51 os menores, ambos após a tosta. Com relação a aceitação do chá mate, os genótipos descafeinados EC29 e EC51 tiveram bom desempenho e, dentre os cafeinados destacaram-se EC43 e EC33. Em ambos os casos, os genótipos foram iguais ou superiores aos produtos comerciais. De maneira geral, os chás descafeinados tiveram melhor aceitação do que os chás cafeinados.

Palavras-chave: capacidade antioxidante; ácidos cafeoilquínicos; llex paraguariensis; metilxantinas; compostos fenólicos 


\section{Introduction}

Leaves of Ilex paraguariensis A.St.-Hil. (Aquifoliaceae) contain numerous bioactive compounds that provide various human health benefits (Heck \& De Mejia, 2007). Recent studies showed that the aqueous extract of yerba mate has antioxidant, anti-inflammatory, and anticarcinogenic properties, as well as helps control obesity, besides being a diuretic and an energetic beverage. These and other benefits are attributed to yerba mate due to the wide range of phytochemical compounds synthesized by the species, especially those belonging to the methylxanthines class (caffeine and theobromine) and phenolic compounds, represented mostly by tannins and chlorogenic acids and their derivatives (Heck \& De Mejia, 2007; Cardozo Junior \& Morand, 2016).

The leaves and branches of yerba mate are mainly consumed in tonics and stimulating beverages, e.g., hot in "chimarrão" or cold in "tererê", and with leaves toasted to obtain mate tea. The importance and abundance of compounds found in yerba mate are known, however, during the process of mate tea production, the raw material goes through different stages, including pre-drying or "zapeco", drying in a rotary dryer or conveyor dryer, grinding (Isolabella et al., 2010), and toasting at temperatures of 180 to $215^{\circ} \mathrm{C}$. Thus, determining the chemical changes that occur during these processes is essential to obtaining products with known phytochemical profile, which in turn allows specific markets to be targeted.

Effective exploitation of the commercial potential of mate tea requires carefully designed consumer profiles, focusing on behavior and preferences to outline more effective marketing and production strategies that meet the needs of the target audience (Godoy et al., 2013). Thus, creating products from selected genotypes should be considered for mate tea production, based on profiles of commercial interest, e.g., different caffeine contents, which could lead to the creation of products with higher added value and market acceptability.

Methylxanthines (caffeine and theobromine), especially caffeine, are stimulating compounds found in various beverages and supplements that consumers often require because of their health benefits, e.g., physical endurance, reduced fatigue and increased attention and mental concentration (Heckman et al., 2010; Valduga et al., 2019). On the other hand, the consumers who seek decaffeinated products prefer lower levels of caffeine due to problems associated with insomnia, hyperactivity, heartburn and tachycardia (Heckman et al., 2010; Valduga et al., 2019). The caffeinated products consumption is not indicated for people with severe cardiovascular diseases, ulcers, nervous tension and insomnia, thus, products with low caffeine levels are alternatives for this consumer group.

Caffeine contributes to the bitter taste of yerba mate infusions (Valduga et al., 2019) and is present in mate tea, but little is known about caffeine levels after processing and how much this compound affects the characteristics of the beverage, especially taste. Some studies related to the consumption and acceptability of mate tea have already been conducted (Godoy et al. 2013; Barboza \& Cazal, 2018), however, this is the first study to report the acceptance of beverages prepared from caffeinated and non-caffeinated genotypes.

Along with caffeine, phenolic compounds also benefit human health in several ways, with yerba mate being a natural source of these compounds, especially those of the caffeoylquinic acid class that are responsible for its high antioxidant activity (Riachi \& De Maria, 2017). From a commercial standpoint, different caffeine levels and high levels of phenolic compounds are interesting because they provide a wider range of potential products and applications, which is an important market to be explored. In this sense, the objective of this study was to analyze the influence of yerba mate toasting on the content of bioactive compounds in different genotypes and the acceptance of caffeinated and decaffeinated mate teas by consumers.

\section{Materials and Methods}

Yerba mate collection, drying and toasting

Eleven genotypes were used according the caffeine content, being five decaffeinated (EC17, EC19, EC22, EC29 and EC51) and six caffeinated (EC25, EC33, EC37, EC40, EC43 and EC49). Caffeine categorization followed Schuhli et al. (2019) and the criteria of the Anvisa standard - RDC N 277 (Brasil, 2005): high caffeine - greater than $1.6 \%\left(16 \mathrm{mg} \mathrm{g}^{-1}\right)$; medium caffeine - between 1.0 and $1.5 \%$ (10 to $15 \mathrm{mg} \mathrm{g}^{-1}$ ); low caffeine: between 0.20 and $0.99 \%$ ( 2 to $9.99 \mathrm{mg} \mathrm{g}^{-1}$ ); and decaffeinated: less than $0.1 \%\left(1 \mathrm{mg} \mathrm{g}^{-1}\right)$. The genotypes used were located in a provenance and progeny trial in Ivaí, Paraná, Brazil $\left(25^{\circ} 01^{\prime} S\right.$, $50^{\circ} 47^{\prime} \mathrm{W}$ and $650-750 \mathrm{~m}$ altitude).

Leaves and branches (15 kg for each genotype) were collected in august 2017, individually processed, following the steps: "zapeco" at $140{ }^{\circ} \mathrm{C}$ for $2 \mathrm{~min}$; removal of branches above $7 \mathrm{~mm}$ and packaging in raffia bags; and drying in a rotary dryer between 40 and $50{ }^{\circ} \mathrm{C}$. For a five-day period, the bags were turned daily for uniform drying.

After drying, the material was ground in an industrial mechanical grinder to obtain green mate tea. The teas were toasted in industrial equipment (Probat ${ }^{\circ}$, Curitiba, Brazil), with an entry and exit temperature of 160 and $205^{\circ} \mathrm{C}$, respectively, for 10 minutes; thus, producing toasted mate tea. In addition to the 11 genotypes, a commercial sample of yerba mate used for "chimarrão" was also analyzed and considered the control sample (called AC), which was toasted through the same process described above.

\section{Preparation of aqueous extracts}

Ten $\mathrm{mg}$ of the uniformly ground samples were weighed (green mate tea and toasted mate tea) for each of the 12 treatments ( 11 genotypes and AC). In each sample were added 2 $\mathrm{mL}$ of ultrapure water. The material was vortexed for 30 seconds and extracted in the Thermomixer Eppendorf ${ }^{\circledR}$ (Hamburg, Germany) for 1 hour, at $60{ }^{\circ} \mathrm{C}$ and $450 \mathrm{rpm}$. The extracts were filtered and used to evaluate the antioxidant capacity, total 
phenolic compounds, methylxanthines and caffeoylquinic acids. The moisture content (evaluated in triplicate by drying in an oven at $105^{\circ} \mathrm{C}$ until constant weight) were used for mass correction in the chemical analyses (AOAC, 2000).

\section{Antioxidant capacity (ABTS and DPPH radicals)}

The antioxidant capacity of extracts via free radical ABTS [2,2-azinobis (3-ethylbenzothiazoline-6-sulfonic acid)] was

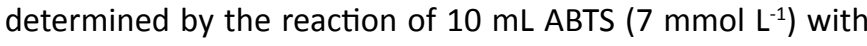
$176 \mu \mathrm{L}$ potassium persulfate $\left(140 \mathrm{mmol} \mathrm{L}^{-1}\right)$ for 16 hours in the dark. Subsequently, $1 \mathrm{~mL}$ of this solution was added to sodium acetate buffer ( $80 \mathrm{mmol} \mathrm{L}^{-1} ; \mathrm{pH} \mathrm{4.5)}$, and the absorbance of the solution was adjusted to $0.7 \pm 0.05$. A $3 \mathrm{~mL}$ aliquot of adjusted solution was added to $30 \mu \mathrm{L}$ of extract. The samples were kept in the dark for 2 hours at room temperature and absorbances were read at $734 \mathrm{~nm}$ (Re et al., 1999, with modifications).

The antioxidant capacity of the extract via free radical DPPH [2,2- diphenyl-1-picril-hydrazil] was determined according to the protocol established by Brand-Willians et al. (1995), with modifications. For the analyzes, $0.1 \mathrm{~mL}$ of extract diluted in $3.9 \mathrm{~mL}$ of DPPH methanol solution $\left(0.06 \mathrm{mmol} \mathrm{L}^{-1}\right)$ (adjusted for absorbance of $0.5 \pm 0.05$ ) was used, kept for 30 minutes in the dark and at room temperature. Subsequently, the absorbances were read at $515 \mathrm{~nm}$.

Antioxidant capacity analyzes were performed with a Shimadzu'-1800 UV/VIS spectrophotometer (Kyoto, Japan). The analytical curves were obtained with Trolox [6-hydroxy2,5,7,8-tetramethylchrome-2-carboxylic acid] between concentrations of 0 to $2,500 \mu \mathrm{mol} \mathrm{L}^{-1}$ to convert the absorbance of the sequestration of ABTS radicals $\left(R^{2}=0.9952\right)$ and between concentrations of 0 and $1,000 \mu \mathrm{mol} \mathrm{L}^{-1}\left(R^{2}=0.9918\right)$ to convert the absorbance of the sequestration of DPPH radicals. The results were expressed in $\mu \mathrm{mol}$ of Trolox Equivalent Antioxidant Capacity per gram of dry sample ( $\mu \mathrm{mol}$ TEAC $\left.\mathrm{g}^{-1}\right)$.

\section{Total phenolic compounds}

The total content of phenolic compounds was determined using the Folin-Ciocalteau spectrophotometric method (Singleton \& Rossi, 1965, with modifications). $0.1 \mathrm{~mL}$ of extract, $6 \mathrm{~mL}$ of distilled water and $0.5 \mathrm{~mL}$ of Folin-Ciocalteau reagent were added to a volumetric flask and stirred for 1 minute. Subsequently, $2 \mathrm{~mL}$ of $15 \% \mathrm{Na}_{2} \mathrm{CO}_{3}$ aqueous solution were added and stirred for another 30 seconds. The final volume was adjusted to $10 \mathrm{~mL}$ with distilled water. The flasks were kept in a dark at room temperature for 2 hours, and later, the absorbances were read in the Shimadzu -1800 UV/VIS spectrophotometer (Kyoto, Japan) at $760 \mathrm{~nm}$. The analytical reference curve was obtained with gallic acid [3,4,5-trihydroxibenzóic acid], with concentrations between 0.25 and $13 \mathrm{mg} \mathrm{L}^{-1}\left(R^{2}=0.9941\right)$. The results were expressed as $\mathrm{mg}$ of Equivalent Gallic Acid per gram of dry sample ( $\mathrm{mg}$ EAG $\left.\mathrm{g}^{-1}\right)$.

\section{Methylxanthines and caffeoylquinic acids}

The methylxanthines and caffeoylquinic acids were determined using High Efficiency Liquid Chromatography
(HPLC) with Shimadzu ${ }^{\circledR}$ liquid chromatograph (UFLC - Kyoto, Japan) controlled by LC Solution software and equipped with automatic injector and UV detector (SPD-20A). For compound separation, the Shim-Pack CLC-ODS (M) column (250 × 4.6 $\mathrm{mm}, \varnothing 5 \mu \mathrm{m})$ was used, with a Shim-Pack CLC G-ODS ${ }^{\circ}$ precolumn $(10 \times 4.0 \mathrm{~mm}, \varnothing 5 \mu \mathrm{m})$, both of which were Shimadzu ${ }^{\bullet}$ (Kyoto, Japan).

The analyzes conditions used were: $20 \mu \mathrm{L}$ injection, $30^{\circ} \mathrm{C}$ with flow of $0.5 \mathrm{~mL} \mathrm{~min}^{-1}$ with mobile phase $A$ eluent $\left(\mathrm{H}_{2} \mathrm{O}\right.$ : Alphatec $^{\circ}$ acetic acid - 99.9:0.1 v/v) and phase B eluent (Merck ${ }^{\circ}$ acetonitrile- $100 \%$ ). The wavelength used to detect the compound was $280 \mathrm{~nm}$ (fixed). The gradient elution program was (minutes): 0-15 (3\% B), 15-20 (3-20\% B), 20-40 (20\% B), 40-45 (20-30\% B), 45- 55 (30\% -100\% B), 55-75 (100 $\%$ B), 75-80 (100-3 \% B) and 80-95 (3\% B).

The identification and quantification of methylxanthines caffeine (1,3,7-trimethylxanthine) and theobromine (3,7-dimethylxanthine) were performed from analytical curves obtained with Sigma ${ }^{\circ}$ standards, between concentrations 0 to $1.0 \mathrm{mg} \mathrm{mL}^{-1}\left(\mathrm{R}^{2}=0.9933\right)$ and from 0 to $0.5 \mathrm{mg} \mathrm{mL}^{-1}\left(\mathrm{R}^{2}\right.$ $=0.9827$ ) for caffeine and theobromine, respectively. The identification of caffeoylquinic acids (3-caffeoiliquinic acid (3-CQA), 4-caffeoylquinic acid (4-CQA), 5-cafeoylquinic acid (5-CQA)) was also performed with Sigma standards and semiquantification was obtained from an analytical curve between contractions of 0 and $10 \mathrm{mg} \mathrm{mL}^{-1}$ of 3-CQA $\left(R^{2}=0.9914\right)$. The results were expressed in $\mathrm{mg}$ of compound per gram of dry sample $\left(\mathrm{mg} \mathrm{g}^{-1}\right)$.

\section{Preparation of teas for acceptance test}

Sixteen grams of the toasted mate tea from each treatment (11 genotypes and $\mathrm{AC}$ ) were boiled in 1 liter of water for 3 minutes. The tea was filtered, and the volume was adjusted with boiling water to 1 liter. As a control treatment, a commercial toasted mate tea (COM) was prepared identically.

\section{Acceptance test}

Two different acceptance tests were performed (affective method - Stone \& Sidel, 2004) by recruiting 110 mate tea consumers for each test. In the first, each consumer evaluated five decaffeinated teas and two control samples ( $A C$ and COM). In the second, each consumer evaluated six caffeinated teas, as well as the two control samples (AC and COM). The recruitment questionnaire included questions about consumers' profile (gender, age, education), consumption habits and availability to participate in the survey. Participants classified the teas with a general degree of acceptance, using structured 9-point hedonic scales, ranging from 1 (I really disliked it) to 9 (I really liked it).

Each participant signed the free and informed consent form (TCLE) to participate in the survey and received $\sim 30 \mathrm{~mL}$ samples of caffeinated or decaffeinated mate teas, heated to $60{ }^{\circ} \mathrm{C}$, and labelled with three-digit numbers, following a balancing order. Consumers that preferred sweet tea were instructed to add the same amount of sugar (or sweetener) to all samples evaluated. Salt crackers and mineral water 
were offered to cleanse their palates between tasting each sample.

Acceptance tests were approved by the Research Ethics Committee of the Faculdades Pequeno Principe (CEP/FPP), certified by the process $\mathrm{n}=17644719.2 .0000 .5580$, referring to the presentation certificate for ethical consideration (CPEC - Number of the Opinion: 3.472.239).

\section{Statistical analyses}

The analyzes of antioxidant capacity, total phenolic compounds, methylxanthines and caffeoylquinic acids were performed in triplicate. Generalized Linear Models, with gamma distribution and multiple comparison between orthogonal contrast treatments, were used along with the Tukey test at $5 \%$. For non-parametric data, the Kruskal Wallis test $(p<0.05)$ and Fisher's test (post-hoc) were used to compare means (for each factor individually). Pearson's correlation ( $p<$ 0.01 and $p<0.05$ ) was used to verify the relationship between total phenolic compounds and antioxidant capacity of the extracts.

To analyze the acceptance of mate tea by consumers, the data was analyzed using the Internal Preference Map, based on Principal Component Analysis (Euclidean distance). In order to identify the consumer segments with the same preference patterns for each tea studied, the Hierarchical Cluster Analysis (Ward method) was used. To observe the differences within the generated segment, the Tukey test with $5 \%$ probability was used.

\section{Results and Discussion}

\section{Influence of toasting on bioactive compounds}

The toasting process influenced the content of bioactive compounds present in the aqueous extract of yerba mate. Table 1 shows a significant reduction in the antioxidant capacity of ABTS and DPPH radicals and in the total phenolic compounds after toasting, as well as significant differences between the genotypes. Among the caffeinated genotypes, EC40 stands out with higher antioxidant capacity (ABTS $=3502$ $\mu \mathrm{mol}$ TEAC $\mathrm{g}^{-1}$; DPPH $=1047 \mu \mathrm{mol}$ TEAC $\mathrm{g}^{-1}$ ) and higher content of total phenolic compounds $\left(81 \mathrm{mg} \mathrm{EAG} \mathrm{g}^{-1}\right)$ after the toasting process. For decaffeinated materials, EC51 showed the highest content of total phenolic compounds ( $65 \mathrm{mg} \mathrm{EAG} \mathrm{g}^{-1}$ ) and high antioxidant capacity (ABTS $=2755 \mu \mathrm{mol}$ TEAC g-1; DPPH $=935$ $\mu \mathrm{mol}$ TEAC $\left.\mathrm{g}^{-1}\right)$, even after toasting.

In general, the studied genotypes showed potential for mate tea production due to the high antioxidant capacity and total phenolic compounds observed (Table 1). Yerba mate is known for its therapeutic effects, and the characterization of the antioxidant activity of teas is indispensable for determining its benefits to human health (Zielinski et al., 2014). Current concerns and the adoption of healthier lifestyles have led consumers to choose products more carefully, increasing their search for more functional foods, e.g., l. paraguariensis, and further supporting the approach performed in this study.

In the work developed by Valduga et al. (2016) there were differences in antioxidant activity between different yerba mate genotypes, which is corroborated by our results (Table 1 ). These authors highlight the importance of such results as they can be used to select plants with higher nutritional and economic values. The results of the present study demonstrate a positive and significant correlation $(p<0.01)$ between antioxidant capacity and total phenolic compounds for the genotypes studied (ABTS, $p=0.81$; DPPH, $p=0.58$ ), showing that phenolic compounds are the main protagonists of antioxidant action in yerba mate, especially due to the presence of chlorogenic acids and their derivatives.

The levels of caffeine, theobromine and total methylxanthines were significantly influenced by the toasting process, with significant differences between studied genotypes (Table 2). Before the toasting process, caffeine levels were below to $1 \mathrm{mg} \mathrm{g}^{-1}$ (considered as decaffeinated genetic materials according to Anvisa) up to levels close to $20 \mathrm{mg} \mathrm{g}^{-1}$ (considered as genotypes with high caffeine levels according to Schuhli et al. (2019) (Table 2; Figure 1).

After toasting process, the EC49 and EC37 genotypes showed the highest levels of caffeine $\left(10.18\right.$ and $7.38 \mathrm{mg} \mathrm{g}^{-1}$, respectively), classified as low caffeine content, according to Schuhli et al. (2019). EC29 and EC51, in the other hand, presented the lowest levels of this compound (0.09 and $0.10 \mathrm{mg} \mathrm{g}^{-1}$, respectively), being classified as decaffeinated

Table 1. Antioxidant capacity of ABTS and DPPH radicals and total phenolic compounds content in aqueous extract of green and toasted mate tea, obtained from caffeinated and decaffeinated genotypes.

\begin{tabular}{|c|c|c|c|c|c|c|}
\hline \multirow{2}{*}{ Genotypes } & \multicolumn{2}{|c|}{ ABTS $^{1 *}\left(\mu \mathrm{mol}_{\mathrm{TEAC}} \mathrm{g}^{-1}\right)$} & \multicolumn{2}{|c|}{$\mathrm{DPPH}^{2}\left(\mu \mathrm{mol} \mathrm{TEAC}^{-1}\right)$} & \multicolumn{2}{|c|}{ Total Phenolic Compounds ${ }^{1 *}\left(\mathrm{mg} \mathrm{EAG} \mathrm{g}^{-1}\right)$} \\
\hline & Green & Toasted & Green & Toasted & Green & Toasted \\
\hline EC 17 & $3363.27 \pm 427.02$ a $A B$ & $2043.80 \pm 247.71 b$ E & $1136.18 \pm 6.56$ a DEF & $872.74 \pm 97.41$ b B & $80.59 \pm 0.10$ a BC & $55.40 \pm 1.03 \mathrm{~b} \mathrm{~B}$ \\
\hline EC 19 & $3700.99 \pm 67.49$ a $A$ & $2180.63 \pm 160.48$ b DE & $1128.17 \pm 2.16$ a G & $975.28 \pm 45.43$ b AB & $85.20 \pm 5.14$ a B & $58.05 \pm 3.19$ b B \\
\hline EC 22 & $3196.30 \pm 254.25$ a $A B C$ & $2341.44 \pm 221.92$ b BCDE & $1157.86 \pm 3.40 a \mathrm{AB}$ & $955.01 \pm 75.23 \mathrm{~b} \mathrm{~B}$ & $83.40 \pm 8.53$ a BC & $54.54 \pm 5.55 b$ B \\
\hline EC 29 & $2705.65 \pm 411.23$ a BC & $2056.15 \pm 222.47 \mathrm{~b} \mathrm{DE}$ & $1156.44 \pm 3.39$ a $A B$ & $985.47 \pm 48.18 \mathrm{~b} \mathrm{AB}$ & $60.88 \pm 5.54$ a D & $57.72 \pm 3.43$ a B \\
\hline EC 51 & $3644.18 \pm 219.29$ a A & $2755.02 \pm 5.14 b B C$ & $1169.70 \pm 1.29$ a A & $935.86 \pm 0.75 \mathrm{~b} \mathrm{~B}$ & $79.63 \pm 13.29$ a BC & $65.18 \pm 2$ \\
\hline EC 25 & $3731.43 \pm 93.05$ a A & $2870.50 \pm 22.68 b$ AB & $1140.07 \pm 1.26$ a CD & $1011.57 \pm 37.47$ b AB & $85.27 \pm 3.73$ a B & $66.28 \pm 7$ \\
\hline EC 33 & $2616.93 \pm 187.13$ a C & $2261.34 \pm 255.13$ a CDE & $1132.52 \pm 5.76$ a FG & $968.22 \pm 57.11$ b AB & $53.18 \pm$ & $58.23 \pm$ \\
\hline EC 37 & $3287.63 \pm 348.36$ a $A B C$ & $2426.66 \pm 241.09$ b BCDE & $1139.71 \pm 1.26$ a CDE & $963.39 \pm 135.35 b \mathrm{bB}$ & $89.28 \pm 8.90$ a $A B$ & $61.51 \pm 7.83 \mathrm{~b} \mathrm{~B}$ \\
\hline EC 40 & $3622.63 \pm 136.03$ a $A$ & $3502.38 \pm 83.69$ a $A$ & $1151.13 \pm 1.28$ a BC & $1047.04 \pm 11.71 \mathrm{~b} \mathrm{~A}$ & $111.27 \pm 2.97$ a A & $81.17 \pm 8.41 \mathrm{~b} \mathrm{~A}$ \\
\hline EC 43 & $2952.59 \pm 376.40$ a $A B C$ & $2386.84 \pm 240.46$ b BCDE & $1134.64 \pm 5.04$ a EFG & $973.91 \pm 61.44$ b AB & $60.95 \pm 7.37$ a D & $56.68 \pm 5.84$ a $B$ \\
\hline EC 49 & $3334.90 \pm 246.36$ a AB & $2583.69 \pm 231.41$ b BCDD & $1130.32 \pm 2.17$ a FG & $985.80 \pm 118.33$ b AB & $79.30 \pm 6.17$ a $B C$ & $65.47 \pm 4.88 \mathrm{~b} \mathrm{AB}$ \\
\hline$A C$ & $2966.05 \pm 165.63$ a $A B C$ & $2151.85 \pm 182.88$ b DE & $1135.49 \pm 8.29$ a DEF & $1001.39 \pm 40.23 \mathrm{~b} \mathrm{AB}$ & $66.83 \pm 4.89$ a CD & $54.95 \pm 3.79 \mathrm{~b} \mathrm{~B}$ \\
\hline
\end{tabular}

Note: Average followed by identical lowercase letters in the same row and uppercase letters in the same column do not differ statistically from each other; 1 : Generalized Linea Models; 2: Kruskal Wallis; *: Significant interaction between drying process factors (dry and toasted) and genotypes. 
Table 2. Methylxanthines content in aqueous extract of green and toasted mate tea, obtained from caffeinated and decaffeinated genotypes.

\begin{tabular}{|c|c|c|c|c|c|c|}
\hline \multirow{2}{*}{ Genotypes } & \multicolumn{2}{|c|}{ Caffeine $^{1}\left(\mathrm{mg} \mathrm{g}^{-1}\right)$} & \multicolumn{2}{|c|}{ Theobromine $^{1}\left(\mathrm{mg} \mathrm{g}^{-1}\right)$} & \multicolumn{2}{|c|}{ Methylxanthines Total ${ }^{1}\left(\mathrm{mg} \mathrm{g}^{-1}\right)$} \\
\hline & Green & Toasted & Green & Toasted & Green & Toasted \\
\hline EC 17 & $0.32 \pm 0.01 \mathrm{a} \mathrm{H}$ & $0.14 \pm 0.02 \mathrm{~b} \mathrm{H}$ & $0.19 \pm 0.02 \mathrm{~b} \mathrm{HI}$ & $0.24 \pm 0.02 \mathrm{a} \mathrm{GH}$ & $0.51 \pm 0.02$ a G & $0.38 \pm 0.03 \mathrm{bl}$ \\
\hline EC 19 & $0.83 \pm 0.11$ a $F$ & $0.20 \pm 0.02 b$ G & $1.47 \pm 0.07 \mathrm{~b} \mathrm{CD}$ & $1.82 \pm 0.11$ a B & $2.30 \pm 0.04 \mathrm{aE}$ & $2.02 \pm 0.09 \mathrm{~b} \mathrm{FG}$ \\
\hline EC 22 & $0.37 \pm 0.01 \mathrm{a} \mathrm{G}$ & $0.25 \pm 0.03 \mathrm{~b} \mathrm{~F}$ & $0.58 \pm 0.07$ a E & $0.24 \pm 0.00 \mathrm{~b} \mathrm{G}$ & $0.95 \pm 0.07$ a FG & $0.49 \pm 0.03 \mathrm{~b} \mathrm{HI}$ \\
\hline EC 29 & $0.09 \pm 0.01 \mathrm{a} \mathrm{J}$ & $0.09 \pm 0.02$ a I & $2.15 \pm 0.11 \mathrm{a} A B$ & $1.64 \pm 0.08$ b CD & $2.24 \pm 0.12 \mathrm{a} E F$ & $1.73 \pm 0.06 \mathrm{~b} \mathrm{GH}$ \\
\hline EC 51 & $0.16 \pm 0.00 \mathrm{al}$ & $0.10 \pm 0.02 \mathrm{bl}$ & $6.09 \pm 0.16$ a $A$ & $4.91 \pm 0.18 \mathrm{~b} \mathrm{~A}$ & $6.25 \pm 0.16$ a $D$ & $5.00 \pm 0.20 \mathrm{~b} \mathrm{E}$ \\
\hline EC 37 & $10.11 \pm 0.91$ a B & $7.38 \pm 0.26$ b B & $0.59 \pm 0.02 \mathrm{a} \mathrm{EF}$ & $0.37 \pm 0.03 \mathrm{~b} \mathrm{~F}$ & $10.70 \pm 0.89$ a $A$ & $7.75 \pm 0.23$ b B \\
\hline EC 40 & $8.48 \pm 0.62$ a C & $6.97 \pm 0.11 b C$ & $0.52 \pm 0.07$ b FG & $0.65 \pm 0.02$ a $E$ & $9.00 \pm 0.69$ a $B C$ & $7.63 \pm 0.12 b \mathrm{BCD}$ \\
\hline EC 43 & $8.72 \pm 0.39$ a C & $6.64 \pm 0.33 b c$ & $0.49 \pm 0.08$ a G & $0.65 \pm 0.08$ a $E$ & $9.21 \pm 0.46$ a B & $7.30 \pm 0.36 b C D$ \\
\hline EC 49 & $19.29 \pm 0.63$ a $A$ & $10.18 \pm 0.39 \mathrm{~b} \mathrm{~A}$ & $0.35 \pm 0.05 \mathrm{a} \mathrm{H}$ & $0.25 \pm 0.11$ a G & $19.64 \pm 0.61$ a $A$ & $10.43 \pm 0.46 \mathrm{~b} \mathrm{~A}$ \\
\hline$A C$ & $7.45 \pm 0.46$ a D & $5.35 \pm 0.24 b D$ & $1.62 \pm 0.13$ a BC & $1.81 \pm 0.13$ a BC & $9.08 \pm 0.52$ a BC & $7.16 \pm 0.35 b \mathrm{D}$ \\
\hline
\end{tabular}

Note: Average followed by identical lowercase letters in the same row and uppercase letters in the same column do not differ statistically from each other; ${ }^{1}:$ Kruskal Wallis.

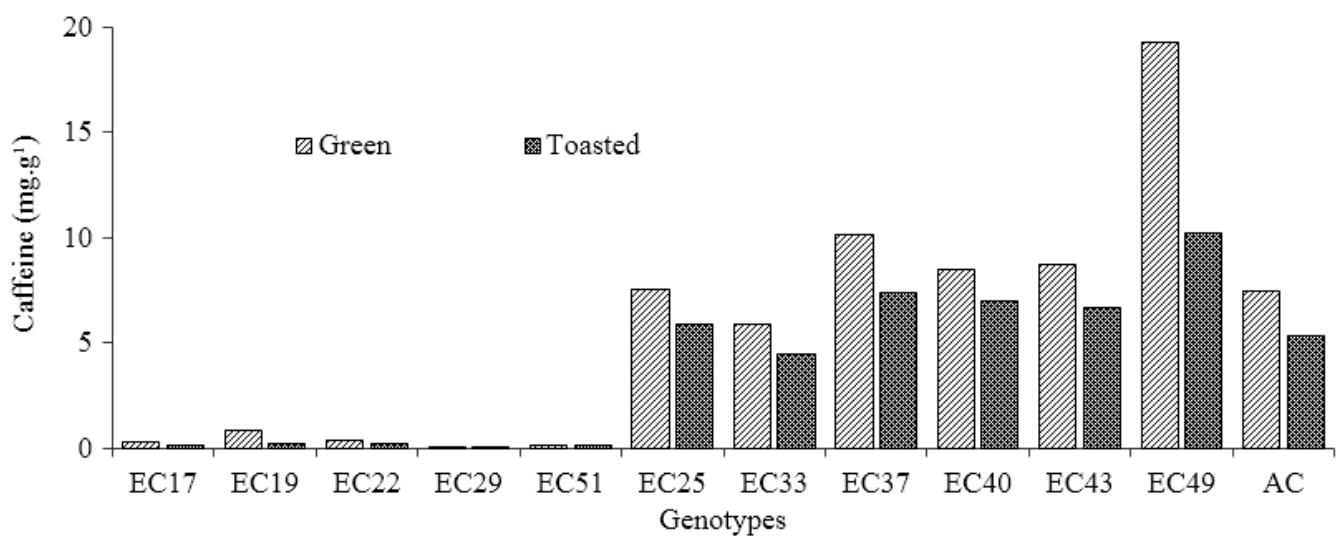

Figure 1. Influence of the toasting process on caffeine content in different genotypes of Ilex paraguariensis A. St.-Hil.

genotypes (Figure 1). Ashihara \& Crozier (1999) reported that low levels of caffeine in Coffea species are related to the reduced biosynthesis activity of the compound. However, Zhu et al. (2019) justify that low levels of caffeine in Camellia sinensis (L.) Kuntze are correlated to the high genetic expression of this compound degradation pathway.

Caffeine is a compound of high interest and is observed in higher quantities when compared to other methylxanthines (theobromine and theophylline) found in yerba mate (Valduga et al., 2019). The significant reduction of caffeine levels throughout industrial processing of yerba mate, as observed in the present study, is somewhat expected and reported in the literature (Esmelindro et al., 2002; Heck \& De Mejia, 2007), being mostly justified by the degradation of compounds due to the high temperatures used during processing. According to Isolabella et al. (2010), phytochemical parameters are directly influenced by raw material processing, and the "zapeco" and drying steps cause the highest rates of caffeine content loss. In this sense, it is worth noting that the toasting process employed in the present study reduced caffeine content by an average of $32 \%$ in the genotypes studied.

In general, theobromine levels changed after toasting process, with some genotypes presenting a significant increase in this compound, while in others there was significant reduction (Table 2). Such reduction can be explained by degradation caused by high temperatures (Esmelindro et al., 2002; Heck \& De Mejia, 2007). Nevertheless, there are no studies in the literature reporting an increase of this compound after processing. However, this result may be related to the initial availability of theobromine in the plant. The high temperatures and mechanical impacts used in yerba mate processing can cause cells rupture (Bastos et al., 2006), which releases compounds that might be contained within the cell wall, for example (Martinez et al, 2014). In addition, processes involving high temperatures reduce the moisture content of the material, increasing soluble solids and depositing more dissolved compounds in the extract (Bastos et al., 2006; Heck \& De Mejia, 2007).

Regarding the differences between the genotypes, the approach taken by Athayde et al. (2007) reported differences in methylxanthine content in five native populations of $I$. paraguariensis, and that the accumulation of theobromine was relatively independent from caffeine accumulation, corroborating the results presented in Table 2. On the other hand, the genotypes EC29 and EC51 presented the lowest levels of caffeine in green mate tea ( 0.09 and $0.16 \mathrm{mg} \mathrm{g}^{-1}$ ) and the highest theobromine levels ( 2.15 and $6.09 \mathrm{mg} \mathrm{g}^{-1}$ ).

The results obtained for caffeoylquinic acids show significant reduction after toasting, as well as significant differences among genotypes (Table 3). For green mate tea, 5-cafeoylquinic 
acid presented the highest levels, followed by 3-CQA and 4-CQA. After the toasting process, 3-cafeoylquinic acid became predominant, indicating that this compound is probably more stable (Table 3), contrary to the results mentioned by Marques \& Farah (2009). Mateos et al. (2018) reported that caffeoylquinic acids are the largest portion of the total phenolic compounds of yerba mate, with 3-caffeolylquinic acid being the most abundant, followed by 5-CQA and 4-CQA, respectively.

It is noteworthy that the control sample (AC) presented lower values of phenolic compounds, antioxidant capacity, methylxanthines and caffeoylquinic acids when compared to the other caffeinated samples. Thus, from the results of these compounds of interest after toasting and among the different genotypes studied, the importance of knowledge about plant materials used to produce mate tea is perceived. Therefore, the industry should focus on the initial characteristics of yerba mate raw material, considering their losses and differences, in order to guarantee products with higher amounts of bioactive compounds to consumers. Knowing the chemical profile of genotypes allows for differentiated products to be developed, adding value and quality to the teas produced. Besides, now industrial methods needs to be developed and evaluated to reduce losses of bioactive compounds.

\section{Acceptance of caffeinated and decaffeinated mate tea}

For decaffeinated teas, the Internal Preference Map (Figure 2-A) revealed that first two dimensions explained
$51.0 \%$ of the variance, with the first component responsible for $35.9 \%$ and the second for $15.2 \%$. The spatial separation suggests differences in consumer acceptance for this tea class, with commercially produced mate teas forming a group ( $A C$ and (COM), a second group formed by the genotypes EC17, EC22, EC29 and EC51, and the EC19 genotype forming a group isolated from the others (Figure 2-A).

For caffeinated teas, there was similar behavior (Figure 2-B), with two main components explaining $43.4 \%$ of the total variation related to consumer acceptance. First component was responsible for $27.7 \%$ of the variance and the second for $15.7 \%$. Spatial separation of caffeinated teas presented three sets: the first formed by two commercial teas and EC43, the second by EC37, EC40 and EC49, and the third grouping teas produced with the genotypes EC25 and EC33. In both analyzes, the low explanatory value of the two main axes can be attributed to consumers who were not trained for this purpose.

Regarding chemical characteristics and groupings formed by mate teas, it is worth highlighting the results of commercial teas ( $A C$ and $C O M$ ) in both acceptance tests. Although the chemical compounds of COM mate tea are not available, the similarity between AC and EC43 teas can be observed for all chemical aspects after toasting (Table 1, 2 and 3). Furthermore, commercial teas come from a mixture of several genotypes, justifying the similar results between the commercial teas and the fact that they differed from the caffeinated and

Table 3. Caffeoylquinic acids in aqueous extract of green and toasted mate tea, obtained from caffeinated and decaffeinated genotypes.

\begin{tabular}{|c|c|c|c|c|}
\hline \multirow{2}{*}{ Genotypes } & Green & Toasted & Green & Toasted \\
\hline & \multicolumn{2}{|c|}{$3-\mathrm{CQA}^{1 *}\left(\mathrm{mg} \mathrm{g}^{-1}\right)$} & \multicolumn{2}{|c|}{ 4-CQA ${ }^{1} *\left(\mathrm{mg} \mathrm{g}^{-1}\right)$} \\
\hline EC 17 & $21.52 \pm 1.03$ a $A B C$ & $11.24 \pm 0.52 b C$ & $13.87 \pm 0.53 \mathrm{a} \mathrm{DE}$ & $6.83 \pm 0.04 \mathrm{~b} E F$ \\
\hline EC 19 & $19.27 \pm 1.30$ a CD & $12.43 \pm 1.26 \mathrm{~b} \mathrm{BC}$ & $16.47 \pm 0.82 \mathrm{a} \mathrm{AB}$ & $7.51 \pm 0.55$ b DE \\
\hline EC 22 & $24.92 \pm 1.47$ a $A$ & $11.46 \pm 1.14 b \mathrm{C}$ & $17.74 \pm 1.09$ a $A$ & $6.33 \pm 0.24 \mathrm{~b} \mathrm{~F}$ \\
\hline EC 29 & $24.31 \pm 1.71$ a $A B$ & $14.17 \pm 0.67 b$ B & $15.89 \pm 1.13$ a $A B C D$ & $8.75 \pm 0.42$ b BC \\
\hline EC 51 & $24.82 \pm 2.63$ a $A$ & $13.28 \pm 0.60 \mathrm{~b} \mathrm{~B}$ & $15.46 \pm 0.54$ a $A B C D$ & $6.72 \pm 0.26 b \mathrm{EF}$ \\
\hline EC 25 & $21.88 \pm 0.28$ a $A B C$ & $14.35 \pm 0.34 \mathrm{~b} \mathrm{~B}$ & $16.21 \pm 1.18$ a $A B C$ & $8.21 \pm 0.57$ b BCD \\
\hline EC 33 & $22.21 \pm 0.98$ a $A B C$ & $13.29 \pm 0.46 \mathrm{~b} \mathrm{~B}$ & $14.01 \pm 0.12$ a CDE & $6.79 \pm 0.27 b \mathrm{EF}$ \\
\hline EC 37 & $20.29 \pm 0.48$ a CD & $12.65 \pm 0.42 \mathrm{~b} \mathrm{BC}$ & $12.87 \pm 1.04$ a $E$ & $7.57 \pm 0.74$ b DE \\
\hline EC 40 & $19.23 \pm 0.28$ a CD & $18.19 \pm 1.09$ a $A$ & $16.53 \pm 0.62$ a $A B$ & $12.90 \pm 0.24 b \mathrm{~b}$ \\
\hline EC 43 & $21.03 \pm 1.81$ a BCD & $13.56 \pm 0.35 b B$ & $13.85 \pm 0.72 \mathrm{a} \mathrm{DE}$ & $9.29 \pm 0.47 b$ B \\
\hline EC 49 & $21.64 \pm 0.56$ a $A B C$ & $13.71 \pm 0.27 b$ B & $14.21 \pm 1.10$ a BCDE & $7.60 \pm 0.18$ b CDE \\
\hline \multirow[t]{2}{*}{$A C$} & $18.11 \pm 1.23$ a D & $11.16 \pm 0.41 b \mathrm{C}$ & $13.78 \pm 0.81$ a DE & $7.15 \pm 0.44 \mathrm{~b}$ DF \\
\hline & \multicolumn{2}{|c|}{$5-\mathrm{CQA}^{1 *}\left(\mathrm{mg} \mathrm{g}^{-1}\right)$} & \multicolumn{2}{|c|}{ CQA Total ${ }^{1 *}\left(\mathrm{mg} \mathrm{g}^{-1}\right)$} \\
\hline EC 17 & $41.90 \pm 2.20 \mathrm{a} \mathrm{AB}$ & $5.80 \pm 0.31 \mathrm{bE}$ & $77.29 \pm 2.97$ a $A B$ & $23.87 \pm 0.86 \mathrm{~b} \mathrm{FG}$ \\
\hline EC 19 & $45.73 \pm 2.22$ a $A$ & $6.11 \pm 0.50 \mathrm{~b} C D E$ & $81.47 \pm 3.85$ a $A$ & $26.05 \pm 2.09 \mathrm{~b}$ DEF \\
\hline EC 22 & $34.96 \pm 1.28$ a DE & $5.52 \pm 0.06 \mathrm{~b} \mathrm{E}$ & $77.62 \pm 2.62 \mathrm{a} A B$ & $23.32 \pm 1.07$ b G \\
\hline EC 29 & $31.12 \pm 1.57$ a $\mathrm{EF}$ & $7.52 \pm 0.30 \mathrm{~b} \mathrm{~B}$ & $71.32 \pm 2.30$ a $B C D$ & $30.44 \pm 0.85 b B$ \\
\hline EC 51 & $33.39 \pm 2.00 \mathrm{a} \mathrm{DE}$ & $6.00 \pm 0.17$ b DE & $73.67 \pm 4.55$ a BC & $25.99 \pm 0.37$ b DEF \\
\hline EC 25 & $35.57 \pm 1.04$ a CD & $7.08 \pm 0.60 \mathrm{~b} \mathrm{BC}$ & $73.67 \pm 1.91$ a BC & $29.64 \pm 0.35$ b BC \\
\hline EC 33 & $28.71 \pm 1.59$ a F & $5.68 \pm 0.16 \mathrm{~b} \mathrm{E}$ & $64.93 \pm 2.49$ a D & $25.75 \pm 0.89 \mathrm{~b}$ DEFG \\
\hline EC 37 & $35.52 \pm 0.18$ a CD & $6.82 \pm 0.47 b \mathrm{BCD}$ & $68.67 \pm 1.62$ a CD & $27.04 \pm 1.62$ b CDE \\
\hline EC 40 & $39.62 \pm 2.19$ a BCD & $10.54 \pm 0.43 \mathrm{~b} \mathrm{~A}$ & $75.39 \pm 1.71$ a $A C$ & $41.63 \pm 1.20 \mathrm{~b} \mathrm{~A}$ \\
\hline EC 43 & $33.89 \pm 1.81$ a DE & $7.00 \pm 0.42 b \mathrm{BC}$ & $68.76 \pm 3.40$ a CD & $29.85 \pm 1.10 b B C$ \\
\hline EC 49 & $36.96 \pm 1.48$ a CD & $7.07 \pm 0.37 b$ DE & $72.81 \pm 1.57$ a BCD & $28.38 \pm 0.80$ b BCD \\
\hline$A C$ & $33.93 \pm 1.21 \mathrm{a} \mathrm{DE}$ & $6.27 \pm 0.49 \mathrm{~b} C D E$ & $65.82 \pm 1.63$ a D & $24.58 \pm 0.54 b$ EFG \\
\hline
\end{tabular}

Note: Averages followed by identical lowercase letters in the same row and uppercase letters in the same column do not differ statistically from each other; ${ }^{1}$ : Generalized Linear Models; *: Significant interaction between drying process factors (dry and toasted) and genotypes 

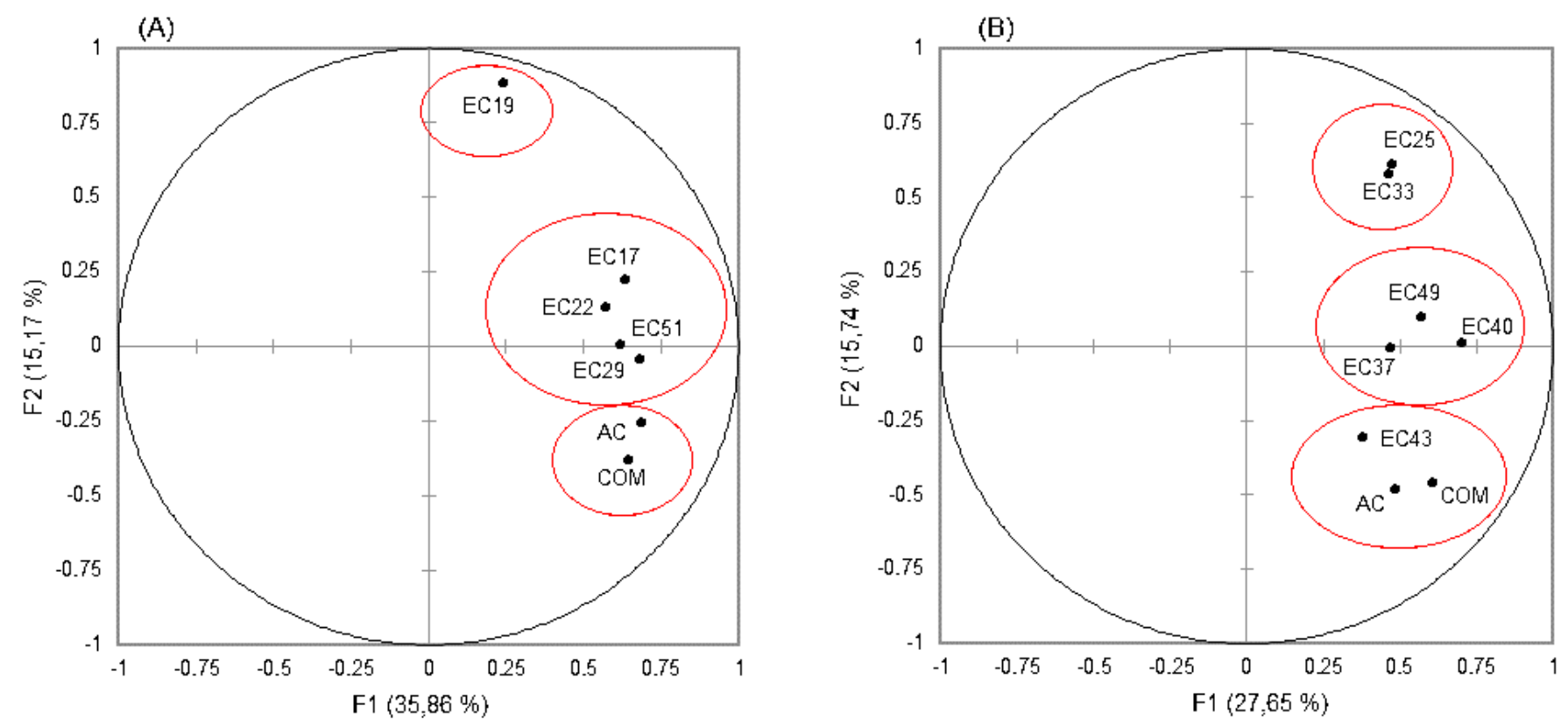

Figure 2. Internal consumer preference map for decaffeinated hot mate tea (A) and caffeinated hot mate tea (B) produced from different genotypes of Ilex paraguariensis A. St.-Hil.

decaffeinated ones. The results obtained in the present study also show that there is interest for both caffeinated and low caffeine mate teas, according to the grades attributed to the tested teas (Table 4).

Segmentation, based on the similarities of consumers' likes or dislikes of the studied teas, identified three groups for both caffeinated and decaffeinated teas, highlighted below the cut lines of the histograms. Figure 3-A presents the segmentations obtained for decaffeinated teas, with $22.7 \%$ of consumers inserted in the first segment, and $55.5 \%$ and $21.8 \%$ in the second and third segments, respectively $(n=110)$ (Table 4). For caffeinated teas (Figure 3-B), the segments were composed of $60.6 \%$ of consumers in the first segment, by $20.2 \%$ in the second and $19.3 \%$ in the third $(n=109)$ (Table 4).
The variations observed in the products, such as intensity of flavor, color and aroma, are perceived differently by each consumer. The consumer preference patterns will affect the different hedonic responses, and these differences form groups with shared hedonic patterns, thus segmenting consumers (Varela et al., 2014), as observed in Table 4. Therefore, segmentation is important for defining market opportunities because it characterizes groups of consumers who share a similar set of needs and desires (Kotler \& Keller, 2012). The study developed by Li et al. (2015) states that preference for a given product may be affected by age, sex and consumption habits, with variations between the choices made by men and women or between young people and adults.

Table 4. Average acceptance, using a hedonic scale, for decaffeinated and caffeinated mate teas produced from different genotypes of Ilex. paraguariensis A. St.-Hil., in each segment.

\begin{tabular}{|c|c|c|c|c|}
\hline \multirow{2}{*}{ Genotype } & \multirow{2}{*}{ Characteristic } & Segment 1 & Segment 2 & Segment 3 \\
\hline & & $(n=25)$ & $(n=61)$ & $(n=24)$ \\
\hline EC17 & \multirow{5}{*}{$\begin{array}{c}\text { Decaffeinated } \\
\text { mate tea }\end{array}$} & $3.40 \pm 1.66 \mathrm{ab}$ & $5.21 \pm 1.88 b$ & $7.13 \pm 0.90 \mathrm{ab}$ \\
\hline EC19 & & $5.00 \pm 1.96 a$ & $5.21 \pm 1.63 b$ & $7.54 \pm 0.83 a$ \\
\hline EC22 & & $4.88 \pm 2.59 \mathrm{a}$ & $5.23 \pm 1.86 b$ & $6.65 \pm 1.26 \mathrm{ab}$ \\
\hline EC29 & & $3.60 \pm 1.73 a b$ & $6.13 \pm 1.78 a b$ & $7.25 \pm 1.11 a b$ \\
\hline EC51 & & $4.72 \pm 2.07 a$ & $5.95 \pm 1.73 \mathrm{ab}$ & $7.17 \pm 0.82 a b$ \\
\hline COM & & $(n=66)$ & $(n=22)$ & $(n=21)$ \\
\hline EC25 & \multirow{4}{*}{$\begin{array}{c}\text { Caffeinated } \\
\text { mate tea }\end{array}$} & $5.86 \pm 1.78 \mathrm{ab}$ & $4.05 \pm 1.40 \mathrm{cde}$ & $5.14 \pm 2.35 \mathrm{ab}$ \\
\hline EC33 & & $6.38 \pm 1.62 a b$ & $5.45 \pm 1.47 \mathrm{abc}$ & $5.62 \pm 1.94 \mathrm{a}$ \\
\hline EC37 & & $5.67 \pm 1.57 b$ & $3.36 \pm 1.76 \mathrm{e}$ & $5.76 \pm 1.55 \mathrm{a}$ \\
\hline EC40 & & $5.97 \pm 1.83 a b$ & $3.59 \pm 1.79 \mathrm{de}$ & $5.05 \pm 1.88 \mathrm{ab}$ \\
\hline
\end{tabular}

Note: $\mathrm{n}=$ number of consumers in each segment; Same letter does not differ significantly from each other by the Tukey test at the $5 \%$ probability level 
(A)

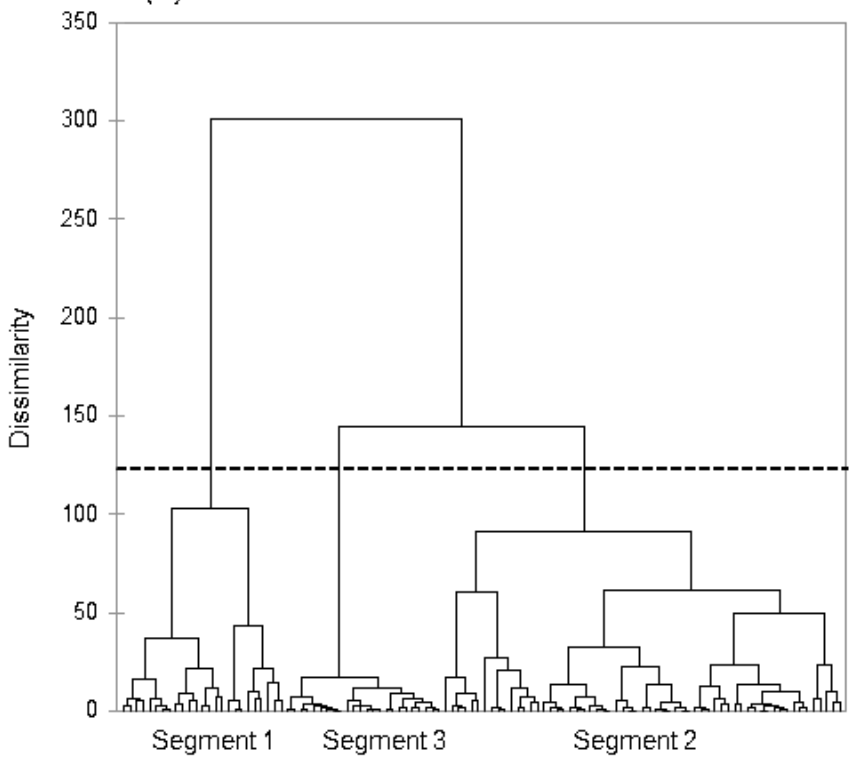

(B)

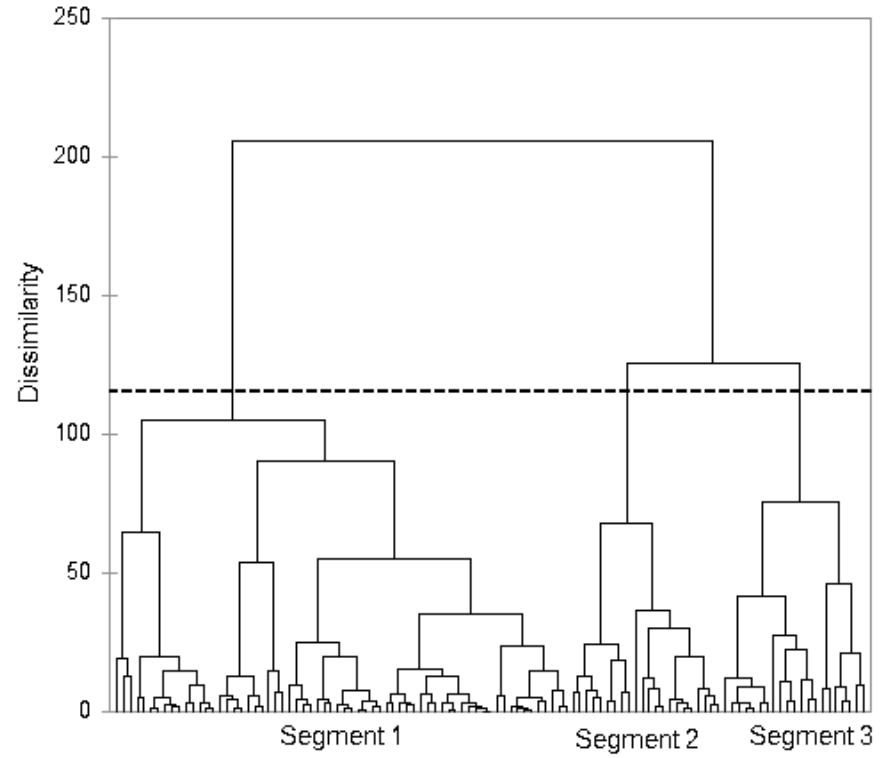

Figure 3. Graphical Representation (Hierarchical Cluster Analysis) of the segmentation of consumers of decaffeinated (A) and caffeinated (B) mate tea produced from different genotypes of Ilex paraguariensis A. St.-Hil.

In segmentation performed for decaffeinated mate teas, there are significant differences between genotypes within all segmented groups (Table 4). Segment $1(n=25)$ attributed lowest scores on the hedonic scale (between "moderately disliked" and "neither liked nor disliked"), mostly represented by people between 26 and 35 years old (36\%), with graduate studies (40\%), and $68 \%$ women. More consumers $(n=61)$ attributed scores considered average on hedonic scale ("neither liked nor disliked" and/or "liked slightly"), represented by consumers between 26 and 35 years old $(31 \%)$, with graduate studies (36\%), and $57 \%$ women. Segment 3 presents highest scores on the hedonic scale ("liked slightly" and/or "moderately"), mostly represented by consumers between 36 and 45 years old, women and high levels of education.

Furthermore, regarding the decaffeinated teas, COM tea obtained lowest averages in first and third segments and was most appreciated by consumers in second segment, with no significant differences for genotypes EC29, EC51 and AC (Table 4). Thus, as previously emphasized, consumer preferences are related to different aspects including age, social class, sex, education level and lifestyle; making acceptance tests complex analyzes that are indispensable for determining target audiences and potential markets. For the decaffeinated genotypes segment, EC29 and EC51 proved to be equal or superior to the commercial samples AC and COM.

For caffeinated teas, a significant difference was observed between genotypes in all segments (Table 4). The highest scores attributed to teas ("neither liked/disliked" and "liked slightly") were from consumers in segment $1(n=66)$, among which $33 \%$ were between 26 and 35 years old, with a high level of education, and mostly women (58\%). In segment 2 $(n=22)$, the AC sample presented the highest average on the hedonic scale (6.41), but did not differ statistically from the samples EC33, EC49 and COM. This segment was composed of $55 \%$ women with higher education and postgraduate degrees.

In the third segment for caffeinated teas $(n=21)$, composed of $48 \%$ men between 26 and 35 years old or 46 to 55 years old (both $24 \%$ ), $43 \%$ of which held graduate degrees, scores were attributed to the indifference region on the hedonic scale. Sample means were between "moderately disliked" to "neither liked/disliked" for all samples, except for the tea produced by AC. In general, for caffeinated teas, genotypes EC43 and EC33 were competitive with commercial samples AC and COM.

From averages presented in Table 4, decaffeinated teas were generally more accepted than caffeinated teas. Such preference may be associated with milder flavors due to low caffeine concentrations. The choice of a particular product can be attributed to different variables related to the habits a consumer develops throughout their lives. However, this result should only be considered as a trend and not as a fact since acceptance tests for each category were not performed by the same consumers. It is also important to mention that some genotypes were more accepted than the commercially available products, which reinforces the need to select more promising raw materials.

From the averages attributed to the two tea types, it is clear that consumers enjoy and generally accept mate teas, as previously observed by Heck \& De Mejia (2007), Godoy et al. (2013) and Barboza \& Cazal (2018). Herein, it was possible to notice that toasting altered the final chemical composition of the product, and that caffeine contents caused differences in the perception and acceptance of mate tea. Such information is essential for producing teas with better quality and phytochemical standards of interest to the consumer.

Acceptance tests should be repeated in other regions with more participants to increase the perception of 
consumer tastes and to conduct future studies with trained sensory panel. In addition, it would be pertinent to perform acceptance tests with both decaffeinated and caffeinated tea samples simultaneously, to better observe and compare the samples.

\section{Conclusion}

The toasting process reduced the antioxidant capacity, total phenolic compounds, methylxanthines and the caffeoylquinic acids of the studied genotypes.

In general, decaffeinated teas were more appreciated by consumers than caffeinated ones.

Among the decaffeinated and caffeinated teas, some genotypes were equally or more appreciated by consumers as commercial teas, indicating their potential for commercial production of mate tea.

\section{Acknowledgments}

The authors thank the Coordination for the Improvement of Higher Education Personnel (Capes) for the doctoral scholarships (Finance Code 001); Faculdades Pequeno Príncipe, especially Professor Maria Rosa Machado Prado, for the assistance in submitting the project to the Ethics Committee; Chimarrão Bitumirim Indústria e Comércio de Erva-mate Ltda and Baldo S/A for the support with this study; The Municipal Market of Curitiba for providing the space to perform acceptance tests; and the Brazilian Agricultural Research Company (Embrapa Florestas) for technical and logistical support.

\section{Literature Cited}

Ashihara, H.; Crozier, A. Biosynthesis and catabolism of caffeine in low-caffeine-containing species of Coffea. Journal of Agricultural and Food Chemistry, n.47, p.3425-3431, 1999. https://doi. org/10.1021/jf981209n.

Association of Official Analytical Chemists - AOAC. Official Methods of Analysis of AOAC International. Fruit and fruit products. 17.ed. Gaithersburg: AOAC, 2000. 32p.

Athayde, M.L.; Coelho, G.C.; Schenkel, E.P. Populational diversity on methylxanthines content of mate (Ilex paraguariensis A. St. Hil. Aquifoliaceae). Latin American Journal of Pharmacy, v.26, n.2, p.275-279, 2007. http://www.latamjpharm.org/trabajos/26 /2/ LAJOP_26_2_2_3_O340BN5NUW.pdf. 22 Apr. 2020.

Barboza, H.C.; Cazal, M.M. Avaliação da influência de características sensoriais e do conhecimento nutricional na aceitação do chámate. Brazilian Journal of Food Technology, v.21, e2017075, 2018. https://doi.org/10.1590/1981-6723.7517.

Bastos, D.H.M.; Fornari, A.C.; Queiroz, Y.S.; Torres, E.A.F.S. Bioactive compounds content of Chimarrao infusions related to the moisture of Yerba Mate (Ilex paraguariensis) leaves. Brazilian Archives of Biology and Technology, v.49, n.3; p.399-404, 2006. https://doi.org/10.1590/S1516-89132006000400007.
Brasil. Agência Nacional de Vigilância Sanitária. Resolução RDC N 277 de 22 de setembro de 2005. Regulamento técnico para café, cevada, chá, erva-mate e produtos solúveis. Diário Oficial da União, v.142, n.184, seção 1, p.379-380, 2005. https:// bvsms.saude.gov.br/bvs/saudelegis/anvisa/2005/anexo/anexo_ res0277_22_09_2005.pdf. 20 Apr. 2020.

Cardozo Junior, E.L.; Morand, C. Interest of mate (Ilex paraguariensis A. St.-Hil.) as a new natural functional food to preserve human cardiovascular health-A review. Journal of Functional Foods, v.21, p.440-454, 2016. https://doi.org/10.1016/j.jff.2015.12.010.

Esmelindro, M.C.; Toniazzo, G.; Waczuk, A.; Dariva, C.; Oliveira, D. Caracterização físico-química da erva mate: influência das etapas do processamento industrial. Food Science and Technology, v.22, n.2, p.199-204, 2002. https://doi.org/10.1590/S010120612002000200016.

Godoy, R.C.B.; Deliza, R.; Gheno, L.B.; Licodiedoff, S.; Frizon, C.N.T.; Rabani, R.H.; Santis, G.G. Consumer perceptions, attitudes and acceptance of new and traditional mate tea products. Food Research International, v.53, n.2, p.801-807, 2013. https://doi. org/10.1016/j.foodres.2013.02.054.

Heck, C.; De Mejia, E. Yerba mate tea (Ilexparaguariensis): a comprehensive review on chemistry, health implications and technological considerations. Journal of Food Science, v.72, n.9, p.138-151, 2007 https://doi.org/10.1111/j.1750-3841.2007.00535.x.

Heckman, M.A.; Weil, J.; De Mejia, E.G. Caffeine (1.3.7-trimethylxanthine) in foods: a comprehensive review on consumption, functionality, safety and regulatory matters. Journal of Food Science, v.75, n.3, p.77-87, 2010. https://doi. org/10.1111/j.1750-3841.2010.01561.x.

Isolabella, S.; Cogoi, L.; López, P.; Anesini, C.; Ferraro, G.; Filip, R. Study of the bioactive compounds variation during yerba mate (Ilex paraguariensis) processing. Food Chemistry, v.122, n.3, p.695 699, 2010. https://doi.org/10.1016/j.foodchem. 2010.03.039.

Kotler, P.; Keller, K.L. Administração de marketing. 14.ed. São Paulo: Pearson Education do Brasil, 2012. 796p.

Li, X.E.; Jervis, S.M.; Drake, M.A. Examining extrinsic factors that influence product acceptance: A Review. Journal of Food Science, v.80, n.5, p.901-909, 2015. https://doi.org/10.1111/1750-3841.12852.

Marques, V.; Farah, A. Chlorogenic acids and related compounds in medicinal plants and infusions. Food Chemistry, v.113, n.4, p.13701376, 2009. https://doi.org/10.1016/j.foodchem.2008.08.086.

Martinez, H.E.P.; Clemente, J.M.; Lacerda, J.S.; Neves, Y.P.; Pedrosa, A.W. Nutrição mineral do cafeeiro e qualidade da bebida. Revista Ceres, v.61, supl., p.838-848, 2014. https://doi. org/10.1590/0034-737x201461000009.

Mateos, R.; Baeza, G.; Sarria, B.; Bravo, L. Improved LC-MSn characterization of hydroxycinnamic acid derivatives and flavonols in different commercial mate (Ilex paraguariensis) brands. Quantification of polyphenols, methylxanthines, and antioxidant activity. Food Chemistry, v.241, p.232-241, 2018 https://doi.org/10.1016/j.foodchem.2017.08.085.

Re, R.; Pellegrini, N.; Proteggente, A.; Pannala, A.; Yang, M.; RiceEvans, C. Antioxidant activity applying an improved ABTS radical cation decolorization assay. Free Radical Biology and Medicine, v.26, n.9, p.1231-1237, 1999. https://doi.org/10.1016/S0891 5849(98)00315-3. 
Riachi, L.G.; De Maria, C.A.B. Yerba mate: An overview of physiological effects in humans. Journal of Functional Foods, v.38, part $A$, p.308-320, 2017. https://doi.org/10.1016/j.jff.2017.09.020.

Schuhli, G.S.; Penteado Junior, J.F.; Wendling, I. Descritores mínimos em cultivares de espécies florestais: uma contribuição para erva-mate. Colombo: Embrapa Florestas, 2019. 22p. (Embrapa Florestas. Documentos, 333). https://www.infoteca. cnptia.embrapa.br/ infoteca/bitstream/doc/ 1117327/1/ Doc3331025final.pdf. 22 Apr. 2020.

Singleton, V.L.; Rossi, J.A.Jr. Colorimetry of total phenolics with phosphomolybdic-phosphotungstic acid reagents. American Journal of Enology and Viticulture, v.16, n.3, p.144-158, 1965. https://www.ajevonline.org/content/16/3/144. 09 Apr. 2020.

Stone, H.; Sidel, J. Sensory evaluation practices. 3.ed. San Diego: Elsevier, 2004. 408p.

Valduga, A.T.; Gonçalves, I.L.; Dartora, N.; Mielniczki-Pereira, A.A.; Souza, L.M. Phytochemical profile of morphologically selected yerba-mate progenies. Ciência e Agrotecnologia, v.40, n.1, p.114120, 2016. https://doi.org/10.1590/S1413-70542016000100011.
Valduga, A.T.; Gonçalves, I.L.; Magri, E.; Finzer, J.R.D. Chemistry, pharmacology and new trends in traditional functional and medicinal beverages. Food Research International, v.120, p.478503, 2019. https://doi.org/10.1016/j.foodres.2018.10.091.

Varela, P.; Beltrán, J.; Fiszman, S. An alternative way to uncover drivers of coffee liking: Preference mapping based on consumers' preference ranking and open comments. Food Quality and Preference, v.32, part B, p.152-159, 2014. https://doi. org/10.1016/j.foodqual.2013.03.004.

Zhu, B.; Chen, L.B.; Lu, M.; Zhang, J.; Han, J.; Deng, W.W.; Zhang, Z.Z. Caffeine content and related gene expression: novel insight into caffeine metabolism in Camellia plants containing low, normal, and high caffeine concentrations. Journal of Agricultural and Food Chemistry, v.67, n.12, p.3400-3411, 2019. https://doi. org/10.1021/acs.jafc.9b00240.

Zielinski, A.A.F.; Haminiuk, C.W.I.; Alberti, A.; Nogueira, A.; Demiate, I.M.; Granato, D. A comparative study of the phenolic compounds and the in vitro antioxidant activity of different Brazilian teas using multivariate statistical techniques. Food Research International, v.60, p.246-254, 2014. https://doi.org/10.1016/j.foodres.2013.09.010. 